\title{
Rat model of chronic lung infections caused by non- typable Haemophilus influenzae
}

\author{
I. MACIVER," S. H. SILVERMAN,† M. R. W. BROWN and T. O'REILLY
}

Microbiology Research Group, Pharmaceutical Sciences Institute, Aston University, Aston Triangle, Birmingham B4 7ET, +Department of Surgery, Queen Elizabeth Hospital, Birmingham B15, and $\ddagger P h a r m a ~ R e s e a r c h, K 125.1 .04$, Ciba-Geigy Limited, Basel, Switzerland, $\mathrm{CH}-4002$

\begin{abstract}
Summary. Patients with chronic obstructive pulmonary disease (COPD) often have chronic or recurrent pulmonary infections with non-typable Haemophilus influenzae. A model of these infections exploited agar bead vehicles to protect the inoculum from rapid clearance, and a chronic lung infection of at least 42 days duration was established in rats. This infection induced increases in serum IgG titres to outer-membrane (OM) and lipo-oligosaccharide (LOS) antigens; immunoblotting demonstrated that this humoral response was directed partly against the outer-membrane proteins (OMPs). Lung lavage fluid also contained an increased titre of IgG antibodies to OM and LOS 42 days after infection. Antibodies produced during infection with one strain of $\boldsymbol{H}$. influenzae cross-reacted with OMPs from another, non-typable $\boldsymbol{H}$. influenzae strain. Despite their encasement in agar beads, pulmonary $H$. influenzae remained susceptible to amoxycillin. This model of chronic pulmonary infections due to non-typable $H$. influenzae appears to resemble the situation in COPD patients and may be useful for experimental therapeutic studies.
\end{abstract}

\section{Introduction}

Chronic pulmonary infections due to non-typable (NT) Haemophilus influenzae cause serious complications in patients suffering from chronic obstructive pulmonary disease (COPD) including bronchitis, bronchiectasis and cystic fibrosis (CF). Although not the cause of the primary disease, such chronic and often recurrent infections are thought to contribute to deterioration of lung function. ${ }^{1}$ Whereas NT $H$. influenzae strains have been shown to be associated with pulmonary infections of $\mathrm{CF}$ patients, ${ }^{2,3}$ their involvement in exacerbations of other COPD is less clear. ${ }^{4}$ However, Murphy and Apicella ${ }^{5}$ have outlined several lines of evidence that, although sometimes ambiguous, suggest the participation of $H$. influenzae in exacerbations of COPD: (1) association of the presence of $H$. influenzae in sputum with sputum purulence and deterioration of clinical condition; (2) rises in antibody titre to $H$. influenzae following exacerbations; (3) clinical improvement following anti-haemophilus chemotherapy; and (4) characterisation of the related respiratory condition of acute febrile tracheobronchitis as an infectious disease involving NT $\boldsymbol{H}$. influenzae.

Received 17 July 1990; revised version accepted 16 Dec. 1990. * Present address: Department of Microbiology, Southwestern Graduate School of Biomedical Sciences, University of Texas Health Center at Dallas, 5323 Harry Hines Boulevard, Dallas, Texas, USA 75235.

$\dagger$ Present address: Wordsley Hospital, Stourbridge DY8 5QX. ‡ Correspondence should be sent to Dr T. O'Reilly.
Cole ${ }^{6}$ has proposed that, following the development of initial COPD symptoms, subsequent damage to the lungs by $H$. influenzae sepsis contributes to the overall clinical condition. Bacterial clearance by antibiotic therapy and subsequent recolonisation induces progressive lung deterioration. Marks ${ }^{7}$ suggested that $H$. influenzae can mediate lung damage due to release of endotoxin invoking inflammatory responses and damaging respiratory cilia as well as immunological damage due to hypersensitivity reactions; indeed, $H$. influenzae lipo-oligosaccharide (LOS) appears to be capable of causing ciliostasis, loss of cilia and epithelial damage. ${ }^{8,9}$ Furthermore, histamine formation by $H$. influenza $e^{10}$ has been implicated as a factor contributing to pathogenesis. ${ }^{11}$

Experimental models of chronic pneumonia have focused on Pseudomonas aeruginosa pneumonia induced with bacteria encased in agar beads to prevent rapid clearance of the inoculum. ${ }^{12}$ The aspects of pathogenesis that have been considered include histopathological changes, ${ }^{12,13}$ the microcolonial nature of bacterial growth in vivo, ${ }^{14}$ the nature of the bacterial cell surface in vivo, ${ }^{15}$ the influence of bacterial toxins on pathogenesis, ${ }^{13,16,17}$ the apparently protective immunogenicity, and subsequent involvement in immune-complex formation, of alginate, ${ }^{18}$ and the nature of the humoral immune response in serum. ${ }^{13,16,17}$

Recently, however, the agar bead model has been applied to the study of $H$. influenzae pulmonary infections. The impaired clearance of the organism due to the agar bead vehicle was demonstrated ${ }^{19}$ and 
animals with pulmonary epithelial mucosal damage induced by hexamethylphosphoramide, or depleted of complement by use of cobra venom factor, were more susceptible to colonisation by $H$. influenzae. ${ }^{20}$ The purpose of the present study was to extend previous work concerning $H$. influenzae in chronic lung infection models by examining the humoral immune response, in both serum and lung lavage fluids, of chronically infected rats. The potential of this model for the study of antimicrobial therapy was also examined.

\section{Materials and methods}

\section{Bacteria}

H. influenzae strains HM 1 and HM 3 were obtained from saline-washed sputum samples from patients with bronchiectasis and confirmed to be NT by failure to agglutinate with capsular-specific antisera. Bacteria from a late exponential phase culture were stored at $-70^{\circ} \mathrm{C}$ in brain heart infusion (BHI) broth supplemented with glycerol $15 \% \mathrm{v} / \mathrm{v}$.

\section{Preparation of inocula for experimental infection}

H. influenzae was grown in 200-ml volumes of BHI broth supplemented with haemin $2.5 \mu \mathrm{g} / \mathrm{ml}$ and NAD $10 \mu \mathrm{g} / \mathrm{ml}$ contained in 1-L erlenmeyer flasks fitted with foam rubber closures. Incubation was at $37^{\circ} \mathrm{C}$, with shaking at $180 \mathrm{rpm}$ and in an atmosphere not enriched for $\mathrm{CO}_{2}$. Cultures were seeded with a $1 \%$ $\mathrm{v} / \mathrm{v}$ inoculum from a 12-h starter culture which had been inoculated with a few colonies from a heated blood (chocolate) agar plate. Bacteria were harvested by centrifugation $\left(17000 \mathrm{~g}, 4^{\circ} \mathrm{C}, 10 \mathrm{~min}\right)$, resuspended in $10 \mathrm{ml}$ of cold buffer $(200 \mathrm{~mm} \mathrm{NaCl}, 20 \mathrm{mM} \mathrm{KCl}$, $20 \mathrm{mM} \mathrm{Na} \mathrm{HPO}_{4}, 20 \mathrm{mM}$ glucose, casamino acids $4 \% \mathrm{w} / \mathrm{v}, \mathrm{pH}$ adjusted to $7 \cdot 4$ with $\mathrm{KOH}$ ), and diluted to contain $10^{9}$ or $10^{11} \mathrm{cfu} / \mathrm{ml}$ (estimated by turbidimetry). The suspension was warmed to $45^{\circ} \mathrm{C}$, and then $5 \mathrm{ml}$ was mixed with $5 \mathrm{ml}$ of molten Noble Agar (Difco) $4 \%$ $\mathrm{w} / \mathrm{v}$ in $\mathrm{H}_{2} \mathrm{O}$ at $45^{\circ} \mathrm{C}$. The agar-bacteria suspension $(5 \mathrm{ml})$ was taken up into a 5 -ml syringe fitted with a $23 \mathrm{~g}$ needle and the suspension was injected quickly into $45 \mathrm{ml}$ of rapidly stirred ice-cold buffer $(100 \mathrm{mM}$ $\mathrm{NaCl}, 10 \mathrm{mM} \mathrm{KCl}, 10 \mathrm{mM} \mathrm{Na} \mathrm{HPO}_{4}, 10 \mathrm{~mm}$ glucose, casamino acids $2 \%$ w/v, pH adjusted to 7.4 with $\mathrm{KOH}$ ) with the needle submerged. This suspension, containing either $c .10^{7}$ or $c .10^{9} \mathrm{cfu} / \mathrm{ml}$, was then placed into $1-\mathrm{ml}$ syringes (fitted with $23 \mathrm{~g}$ needles) in $0 \cdot 2-\mathrm{ml}$ amounts, and stored on ice until used. A slurry of amorphous agar particles encasing the bacteria was produced by this method and the particles ranged from $(24 \times 30) \mu \mathrm{m}$ to $(90 \times 120) \mu \mathrm{m}$ in cross section, as determined by microscopy. When examined by microscopy, almost all of the bacteria appeared to be associated with the agar beads. When subjected to a parallel procedure without agar, to determine the total $\mathrm{cfu} / \mathrm{ml}$, no significant loss of bacterial viability occurred.

\section{Infection procedure}

The infection procedure was based on that described by Cash et al. ${ }^{12}$ Female Sprague-Dawley rats (180$240 \mathrm{~g}$; specific pathogen free; Harlan Olac Ltd, Bicester, Oxon) were sedated with $0.5 \mathrm{mg}$ of Hypnorm (fentanyl citrate plus fluanisone; Janssen) given by subcutaneous (s.c.) injection, and then anaesthetised with an intramuscular injection of midazolam (Hypnovel, Roche) $0.5 \mathrm{mg}$ and Hypnorm $1 \mathrm{mg}$; pentobarbital was found to be an unsuitable anaesthetic due to severe respiratory depression. Just before surgical exposure of the trachea, rats were given naloxone hydrochloride (Narcan, DuPont) $0.02 \mathrm{mg}$ s.c. to promote respiration. The trachea was exposed by a vertical incision in the neck and each rat was inoculated intratracheally, by direct needle puncture, with $0.2 \mathrm{ml}$ of the agar bead suspension warmed to room temperature. The animal was held in an upright position for a few seconds, then placed ventral side down until breathing returned to normal. The wound was closed with two 12-mm Michele clips and the animal was allowed to recover from anaesthesia. Fewer than $2 \%$ of the animals died from immediate respiratory failure. Control animals were either not operated upon or received sterile agar beads.

Animals (four or five in each set) were killed at intervals by sedation and anaesthesia as described above. Blood was collected by puncture of the vena cava, and the lungs were subsequently excised. Serum was prepared and stored at $-20^{\circ} \mathrm{C}$. The surface of the lungs were rinsed with sterile saline $(\mathrm{NaCl} 0.9 \% \mathrm{w} / \mathrm{v})$, weighed in sterile petri dishes and then homogenised in ice-cold saline, in a glass tissue homogeniser with a teflon plunger fitted to a power drill in a drill press. Samples of lung homogenate were serially diluted in BHI broth and spread on to chocolate or BHI agar plates which were then incubated for $24 \mathrm{~h}$ at $37^{\circ} \mathrm{C}$ in a candle jar or a $\mathrm{CO}_{2} 5 \%$ incubator before viable counting. Heparinised blood $(0 \cdot 1 \mathrm{ml})$ was also cultured on chocolate agar plates.

Lung lavage fluid was collected post mortem by infusion of $2.0 \mathrm{ml}$ of saline through a catheter secured in the trachea; c. $25-50 \%$ of this volume could be recovered. This lavage fluid was centrifuged briefly and the supernate was removed and stored at $-20^{\circ} \mathrm{C}$.

\section{Determination of haematological parameters}

Blood was placed into dry heparinised tubes and leucocyte count, erythrocyte count, and haemoglobin concentration were determined with a Sysmex Microcell Counter (model CC-170M).

\section{Preparation of bacterial antigens}

Outer membranes (OMs) were prepared from bacteria grown in BHI broth containing protopor- 
phyrin IX $5 \mu \mathrm{g} / \mathrm{ml}$ and NAD $10 \mu \mathrm{g} / \mathrm{ml}$. Cell-free extracts were prepared from stationary phase $(18 \mathrm{~h})$ bacteria harvested by centrifugation $(20000 \mathrm{~g}, 20 \mathrm{~min}$, $4^{\circ} \mathrm{C}$ ) and disrupted in a French pressure cell operating at $69 \mathrm{Kpa}\left(1 \times 10^{4} \mathrm{lb} / \mathrm{in}^{2}\right)$. These were then incubated with N-lauryl sarcosine (sarkosyl) $2.5 \% \mathrm{w} / \mathrm{v}$ at room temperature for $30 \mathrm{~min}$. After slow centrifugation $\left(16000 \mathrm{~g}, 10 \mathrm{~min}, 4^{\circ} \mathrm{C}\right)$ to remove large debris, the supernate was subjected to high speed centrifugation $\left(180000 \mathrm{~g}, 1 \mathrm{~h}, 4^{\circ} \mathrm{C}\right)$. The resulting pellet was resuspended in $\mathrm{H}_{2} \mathrm{O}$, collected by centrifugation $(180000 \mathrm{~g}$, $1 \mathrm{~h}, 4^{\circ} \mathrm{C}$ ) and finally resuspended in a small volume (c. $0.5 \mathrm{ml}$ ) of $\mathrm{H}_{2} \mathrm{O}$. The protein content of each $\mathrm{OM}$ preparation was determined by the method of Lowry et al. $^{21}$

LOS was prepared from stationary phase $H$. influenzae strain HM 1 , grown in BHI broth containing protoporphyrin IX, by the phenol-chloroform-ether extraction method of Galanos et al. ${ }^{22}$

\section{ELISA}

Outer membranes. Microtitration plates were coated with $\mathrm{OM}$ suspension (protein $10 \mu \mathrm{g} / \mathrm{ml}$ in $50 \mathrm{mM}$ carbonate buffer, $\mathrm{pH} 9 \cdot 6), 250 \mu \mathrm{l} /$ well, for $18 \mathrm{~h}$ at $4^{\circ} \mathrm{C}$. Plates were then washed with phosphate-buffered saline (PBS; $140 \mathrm{mM} \mathrm{NaCl}, 2.7 \mathrm{mM} \mathrm{KCl}, 1.5 \mathrm{mM}$ $\left.\mathrm{KH}_{2} \mathrm{PO}_{4}, 8.1 \mathrm{mM} \mathrm{Na} \mathrm{HPO}_{4}, \mathrm{pH} 7.4\right)$ containing Tween $200.5 \% \mathrm{v} / \mathrm{v}$ (PBS-Tween), and non-specific binding sites were blocked for $1 \mathrm{~h}$ at room temperature with PBS-Tween containing bovine serum albumin $1 \% \mathrm{w} / \mathrm{v}$. After washing with PBS-Tween, $200 \mu \mathrm{l}$ of serum or lung lavage fluid was added to the first well of each row, and $100 \mu \mathrm{l}$ of this was serially diluted in PBS-Tween in the remaining wells. After incubation for $2 \mathrm{~h}$ at room temperature, plates were washed with PBS-Tween. Horseradish peroxidase (HRP)-conjugated goat anti-rat IgG (Sigma) diluted 1 in 1000 in PBS-Tween was added, $200 \mu \mathrm{l}$ to each well, and the plates were incubated at room temperature for $2 \mathrm{~h}$. Absorption of the conjugate with OMs obtained from strain HM 1 was required to reduce non-specific binding. After washing, $200 \mu \mathrm{l}$ of substrate solution $\left(3,3^{\prime}, 5,5^{\prime}\right.$ tetramethylbenzidine $0 \cdot 1 \mathrm{mg} / \mathrm{ml}$ in $100 \mathrm{~mm}$ sodium acetate-sodium citrate buffer, $\mathrm{pH} 6.0$, supplemented with $\mathrm{H}_{2} \mathrm{O}_{2} 30 \% \mathrm{v} / \mathrm{v} 8 \mu \mathrm{l} / 100 \mathrm{ml}$ just before use) was added. Plates were incubated for $10 \mathrm{~min}$, and the reaction was stopped by the addition of $50 \mu \mathrm{l}$ of $2 \mathrm{~N} \mathrm{H}_{2} \mathrm{SO}_{4}$. Absorbance at $450 \mathrm{~nm}$ was measured with a plate reader and the mean absorbance of control wells, containing no antigen, or no serum or lung lavage fluid (consistently $<0 \cdot 2$ ), was subtracted from the test wells. Corrected absorbance readings of $>0 \cdot 1$ were considered to be positive. Results are expressed as the $\log _{2}$ of the highest dilution that gave a positive reaction.

Lipo-oligosaccharide. ELISA to detect antibodies to purified LOS was done as above except that Tween 20 was omitted from all reagents; $250 \mu \mathrm{l}$ of LOS antigen $10 \mathrm{mg} / \mathrm{ml}$ was added to each well.

\section{SDS-PAGE and immunoblotting}

Outer-membrane proteins (OMPs) were separated by sodium dodecyl sulphate-polyacrylamide gel electrophoresis (SDS-PAGE) in 1.5-mm thick gels containing acrylamide $10 \%$ as described by Niven et $_{\text {al. }}{ }^{23}$ Samples containing $40 \mu \mathrm{g}$ of protein were loaded on to each well and the separated polypeptides were either stained with Coomassie Blue, or used in immunoblotting. Polypeptides were transferred electrophoretically to nitrocellulose paper, and antigenic sites were visualised by the method of Towbin et al. ${ }^{24}$ with Trisglycine-methanol as the transfer buffer. Tris-saline buffer (pH 7.4) containing Tween $200.3 \% \mathrm{v} / \mathrm{v}$ was used for blocking and for diluting antisera (1 in 25) and goat anti-rat IgG HRP conjugate (1 in 1000). Paper-bound immune complexes were visualised with 4-chloro-1-naphthol. The HRP conjugate required absorption with isolated OMs from strain HM 1 to reduce non-specific binding to transferred OMPs. However, such treatment could not completely eliminate binding to the major 40-K da OMP. Amido black staining of the nitrocellulose paper showed that the transfer of OMPs was qualitatively complete, but Coomassie Blue staining of gels after electrotransfer indicated that the transfer was quantitatively incomplete.

\section{Therapy of infection}

Two weeks after the injection of $10^{6} \mathrm{cfu}$ of $H$. influenzae strain HM 1 , animals were given a single intramuscular dose of Augmentin (amoxycillin + clavulanic acid; Beecham) $30 \mathrm{mg} / \mathrm{kg}$. Control animals received pyrogen-free water. Animals were killed at intervals and the lungs were homogenised and their bacterial content determined as described above.

The MIC of amoxycillin for the bacterial strain was determined by the tube dilution method with BHI broth and an inoculum sufficient to give $10^{5} \mathrm{cfu} / \mathrm{ml}$ final concentration. The MBC was determined by subculture (10 $\mu \mathrm{l}$ of each dilution) to chocolate agar plates where the absence of growth was considered indicative of a bactericidal amoxycillin concentration.

\section{Statistical analyses}

The statistical significance of differences between groups was determined with the two-tailed $t$ test.

\section{Results}

After the intratracheal administration of $H$. influenzae strain HM 1 in agar-beads, rat lungs became chronically colonised and this condition persisted for at least 42 days (fig. 1A). In the examples presented here, inocula of $10^{6 \cdot 7}$ (low inocula) or $10^{8 \cdot 1}$ (high inocula) cfu were used. Despite the use of 

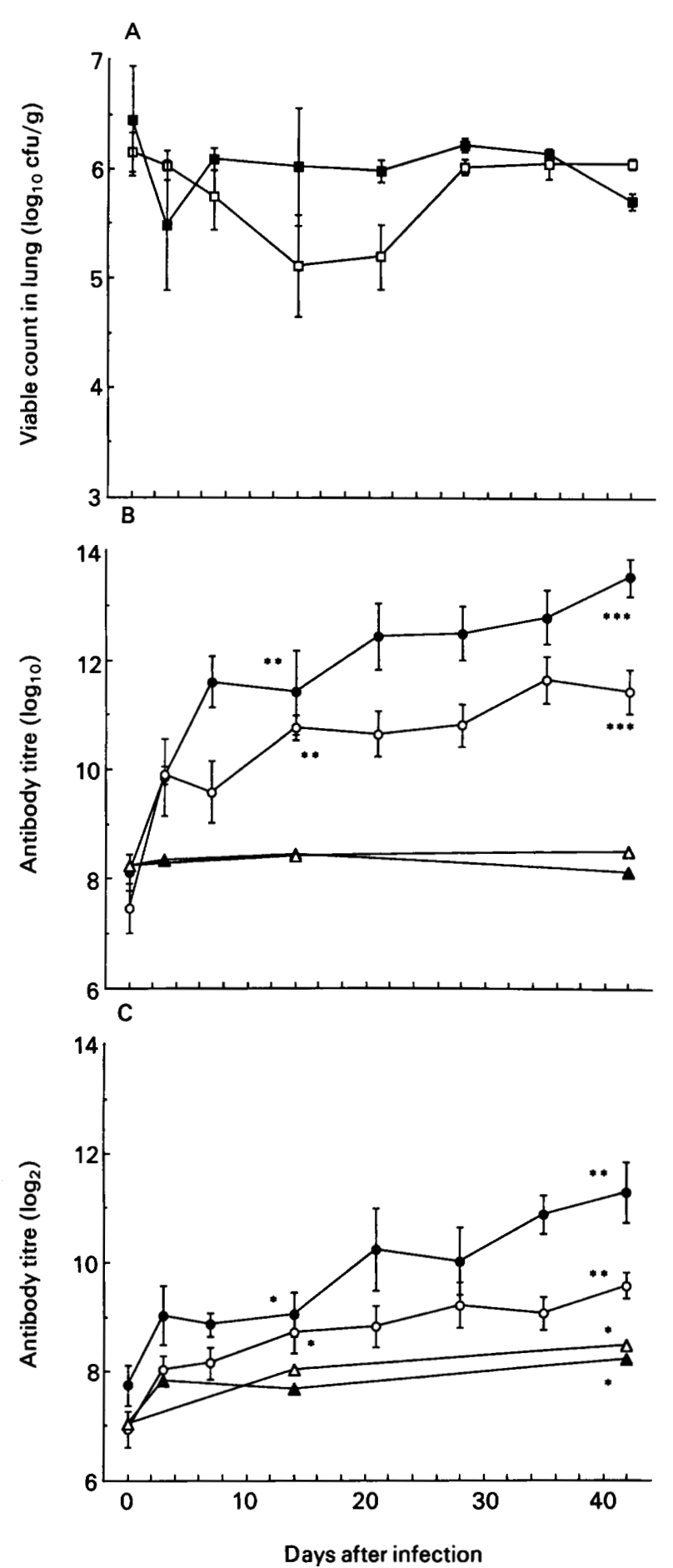

Fig. 1. Pulmonary persistence and serum antibody response to NT $H$. influenzae. A, pulmonary $H$. influenzae $\mathrm{HM} 1$ population after injection of $10^{6 \cdot 7}(\square)$ or $10^{8 \cdot 1}$ ( $\square$ cfu. B, serum antibody titre directed against OM components of strain HM 1 of unmanipulated control animals $(\triangle)$ or animals given sterile agar beads $(\Lambda)$, or $10^{6 \cdot 7}$ (O) or $10^{8 \cdot 1}(\bigcirc)$ cfu. C, serum antibody titre directed against LOS purified from strain HM 1 (symbols as in panel B). Values presented are means ( $n=4$ or 5$)$ and the SEM is either encompassed by the size of the symbol or represented by vertical bars. Titres from infected animals were compared to age-matched controls and in panel $\mathrm{C}$, day 42 controls are compared to day 0 controls; ${ }^{*} \mathrm{p}<0.02$, ${ }^{* *} \mathrm{p}<0.002,{ }^{* * *} \mathrm{p}<0.001$.

different inocula, the animals appeared to contain the same initial numbers of $\mathrm{cfu} / \mathrm{g}$ of lung (fig. 1A). However, although similar numbers of beads were produced and injected into the animals, those of the low inocula were estimated to contain three bacteria/bead, whereas those of the high inocula contained 44 bacteria/bead. As the lung homogenisation procedure was unlikely to disrupt the agar beads, the animals thus appeared to contain the same number of $\mathrm{cfu} / \mathrm{g}$ of lung despite the differences in the initial pulmonary bacterial load. Contamination of the lungs by non-haemophilus bacteria occurred, but was $<1 \%$ of the $H$. influenzae population at day 0 and, although this contamination increased during the course of the infection, it was $<32 \%$ by day 42 . In some animals given $10^{6 \cdot 5} \mathrm{cfu}$, the infection persisted for 70 days with a mean count of $10^{5.8} \mathrm{cfu} / \mathrm{g}$ of lung, although contaminants were in equal numbers by this time.

The presence of pulmonary $H$. influenzae did not appear to affect the rate of weight gain as compared to unmanipulated controls. Furthermore, haematological parameters (leucocyte and erythrocyte counts, haemoglobin content) did not demonstrate any apparent effect of pulmonary infection; infected animals showed age-dependent increases similar to control (unmanipulated) animals and all values were within normal ranges. Blood from infected or control animals contained $<10 \mathrm{cfu}$ of bacteria/ml at any sampling time.

This persistent infection was accompanied by increasing titres of serum antibodies directed against OMs derived from strain HM 1 (fig. 1B). Animals given sterile agar beads had titres not significantly different from unmanipulated controls and these two groups were then combined for statistical comparisons with infected animals. Although in both of these groups there was a slight increase in titre with increasing age, the titres at day 42 were not significantly different from those at day 0 ( $p>0 \cdot 1$; fig. 1B). From initial titres, indicative of naturally occurring antibodies, there was a rapid rise in antibodies against OMs in infected animals. At 14 days after infection, these increases were statistically significant (fig. 1B; low inoculum $\mathrm{p}<0.001$; high inoculum $\mathrm{p}<0.02$ compared to day 14 controls). This trend continued and animals that had received a larger inoculum of $H$. influenzae had a higher titre by day 42 than those that had received lower inocula (fig. 1B; low or high inocula $\mathrm{p}<0.001$ compared to day 42 controls).

Serum antibodies directed against LOS derived from strain HM 1 also increased, from a titre indicative of naturally occurring antibodies, to become significantly different (low or high inoculum $\mathrm{p}<0.002$ ) from controls at 42 days after infection (fig. 1C). Unmanipulated control animals and rats given sterile agar beads had titres not significantly different from each other, although, in contrast to the results with OMs as antigen, the titres increased with increasing age, becoming significantly different from initial titres by day 42 ( $p<0.02$; fig. $1 \mathrm{C})$.

Specific antibodies were also detected in lung lavage fluid of infected rats. In unmanipulated, age-matched, control animals only very low levels of antibodies against $O M$ and LOS antigens were found in contrast 
to infected animals at 42 days after infection $(\mathrm{p}<0.05$; table).

The humoral immune response included antibodies directed against OMPs of strain HM 1 (fig. 2A). Fig. 2B shows a series of immunoblots with sequentially obtained sera and indicates an increasing intensity of antibody binding to several OMPs during the course of infection, with antibodies binding to the $30-, 32-, 40-, 80-$ and $82-\mathrm{Kda}$ OMPs. A band at $23 \mathrm{Kda}$ was also antigenic, which may represent, in part, the anti-LOS response. Some OMPs, barely visible on the stained gels, appear to be strongly antigenic (e.g. the 86-Kda polypeptide). Antibodies to OMPs were also detected in sequentially obtained lung lavage fluid (fig. 2C), notably demonstrating reactivity with the 40-Kda OMP.

The OMP profile of $H$. influenzae HM 3 is shown in fig. 3A. Sera obtained from rats infected with strain HM 1 reacted with several OMPs from strain HM 3 (fig. 3B). Pre-infection sera appeared to recognise OMPs at 63 and $86 \mathrm{Kda}$ from strain HM 3, but such antibodies were apparently lost during infection with strain HM 1. Lung lavage fluid from rats infected with strain HM 1 contained antibodies that recognised the 40- and 44-Kda OMPs of strain HM 3 (fig. 3B). Animals infected with strain HM $3\left(10^{8 \cdot 7} \mathrm{cfu} / \mathrm{rat}\right)$
Table. $H$. influenzae antigen-specific antibody content of lung lavage fluid obtained 42 days after infection

\begin{tabular}{c|ccc}
\hline \multirow{2}{*}{ Antigen } & \multicolumn{3}{|c}{ Mean $\log _{2}$ antibody titre (SEM) in } \\
\cline { 2 - 4 } & controls* & infected rats & p value \\
\hline OMs & $1.47(0.9)$ & $8.82(1.4)$ & $<0.05$ \\
LOS & $2.86(0.9)$ & $7.82(0.9)$ & $<0.05$ \\
\hline
\end{tabular}

* Age-matched animals; $n=4$ for both infected and control groups.

produced antibodies binding to the 30-, 32- and 40Kda OMPs of strain HM 1 (fig. 3D); some reactivity was also seen with the 80-, 82- and, perhaps, the 86Kda OMPs.

The MIC of strain HM 1 for amoxycillin was $0 \cdot 25-$ $0.5 \mathrm{mg} / \mathrm{L}$ and the $\mathrm{MBC}$ was $0.5-1.0 \mathrm{mg} / \mathrm{L}$. Despite encasement in agar beads, $H$. influenzae remained susceptible to amoxycillin in vivo (fig. 4). A single dose of Augmentin $(30 \mathrm{mg} / \mathrm{kg})$ resulted in at least a $98 \%$ reduction $(\mathrm{p}<0.005)$ in pulmonary $H$. influenzae in rats which had been given $10^{6.9}$ cfu intratracheally 2 weeks previously. Since a sub-therapeutic dose was used, $H$. influenzae was not eradicated, and the bacterial population subsequently increased to pretreatment levels (fig. 4).

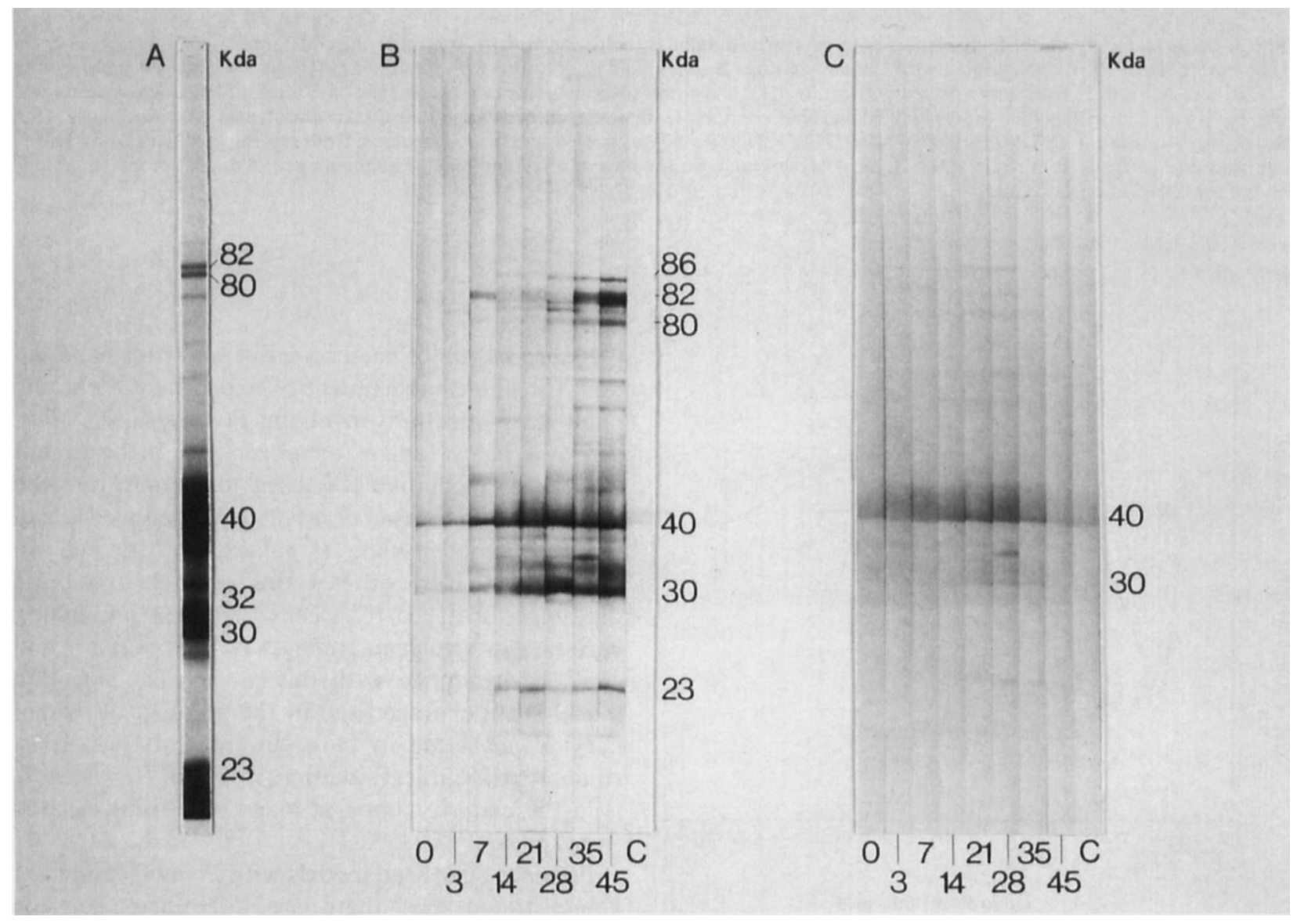

Fig. 2. Serum antibody response to $H$. influenzae strain HM 1 OMPs as determined by immunoblotting. OMPs were separated by SDSPAGE and stained with Coomassie Blue (A) or transferred to nitrocellulose paper $(\mathbf{B})$. Antibodies in pooled sera $(\mathrm{n}=\mathbf{4}$ or 5 ) forming paperbound immune complexes were detected with anti-rat IgG peroxidase conjugate; $\mathrm{C}$, a similar immunoblot but with pooled lung lavage fluid $(n=4$ or 5 ). Numbers below the lanes represent the days after infection when serum or lung lavage fluid was obtained; lane $C$ is a control with conjugate but not primary antiserum. 


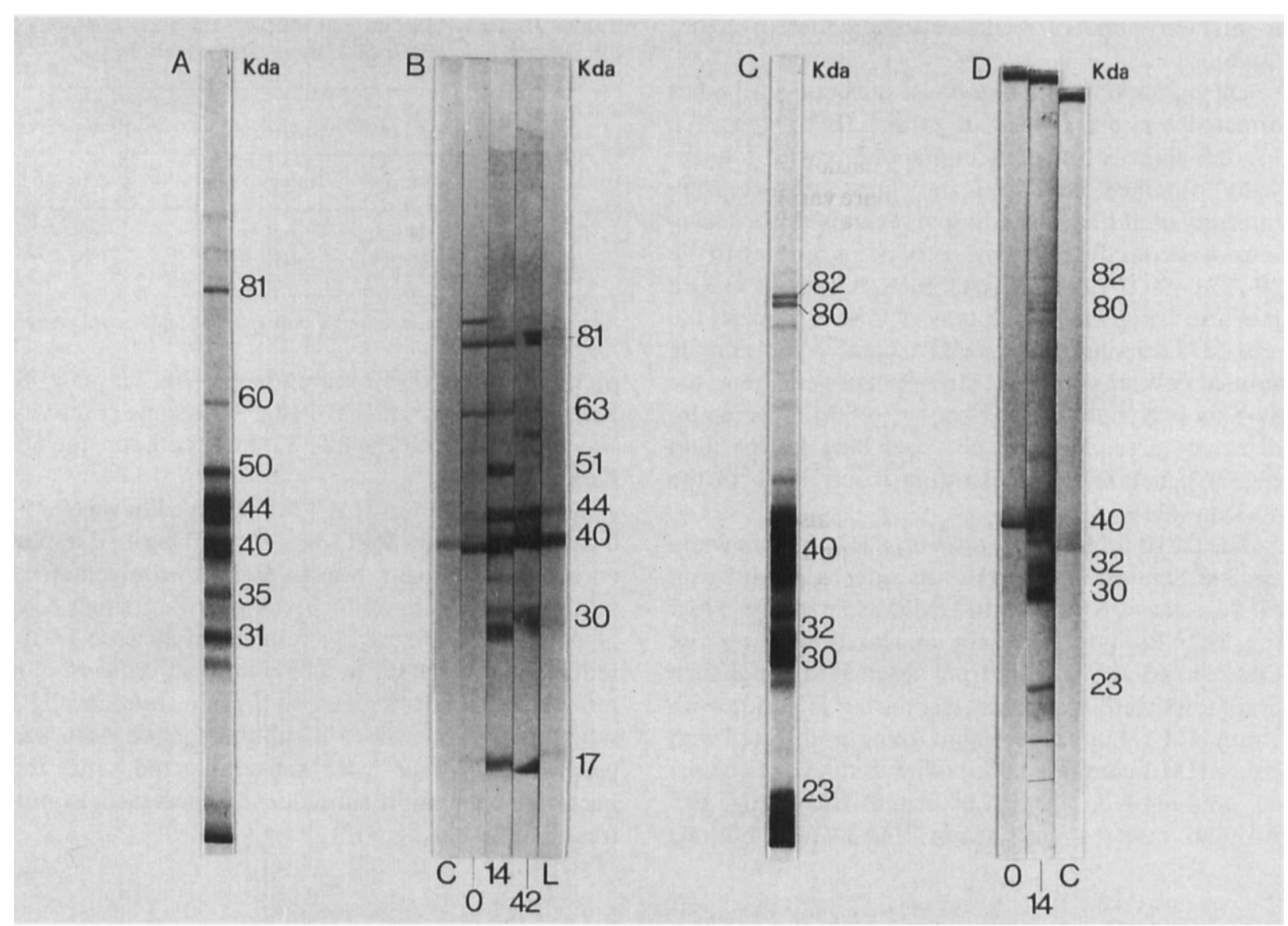

Fig. 3. Cross reactivity of antibody responses to persistent pulmonary infection with $H$. influenzae. A, OMP profile of $H$. influenzae strain HM 3 after SDS-PAGE and staining with Coomassie Blue. B, immunoblots obtained with separated OMPs as antigens and probing with pooled sera $(n=4$ or 5) from rats infected with strain HM 1 . Numbers below the lanes represent the days after infection when serum was obtained; lane $L$ is with pooled $(n=5)$ lung lavage fluid obtained 42 days after infection and lane $C$ is a control reaction with conjugate but not primary antiserum. C, OMP profile of strain HM 1. D, reactivity of pooled sera $(n=5)$, obtained from rats infected with strain HM 3, against OMP antigens from strain HM 1. Lane 0, sera obtained at the time of infection; lane 14, sera obtained 14 days after infection; lane $\mathrm{C}$, is a control reaction as above.

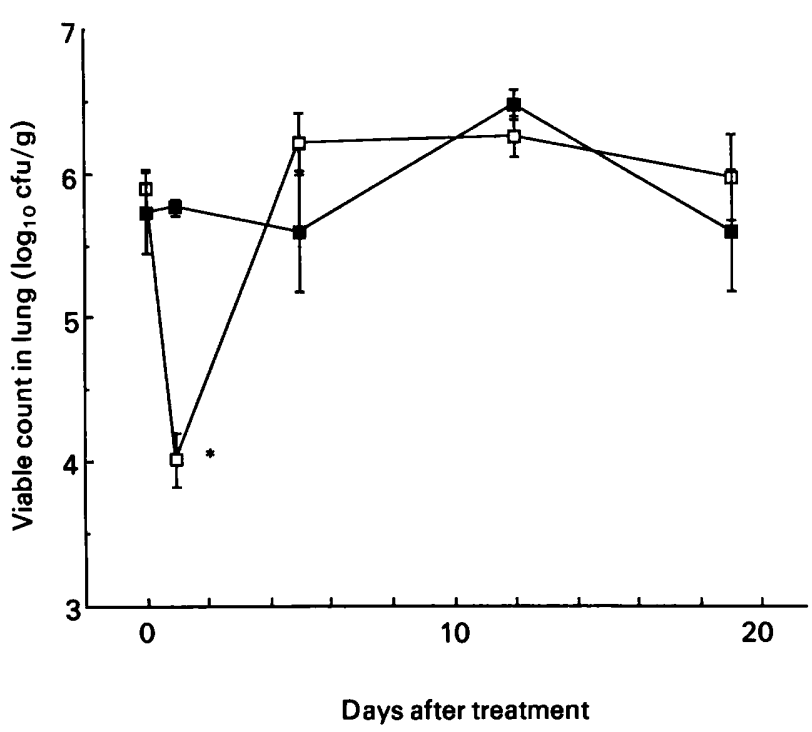

Fig. 4. Amoxycillin-induced reduction of pulmonary $H$. influenzae. A single dose of Augmentin $(30 \mathrm{mg} / \mathrm{kg}$ ) was administered 14 days after infection ( $\square)$; controls received pyrogen-free water ( $\square$ ). Values are means $(n=4)$ and the SEM is either encompassed by the size of the symbol or represented by vertical bars; ${ }^{*} \mathrm{p}<0.005$.

\section{Discussion}

Incorporation of bacteria into agar beads has been useful in the establishment of experimental chronic pulmonary infections involving $P$. aeruginosa ${ }^{13}$ Bordetella pertussis ${ }^{25}$ and $H$. influenzae. ${ }^{19,20}$ In the present study, this technique was used to demonstrate the persistent colonisation of rat lungs by a single clinical isolate of noncapsulate $H$. influenzae. Although we have found that two other strains were able to colonise the lungs for at least 2 weeks (data not presented), variation in virulence amongst isolates is likely and could be examined with this model. The infection model is not characterised by the presence of pulmonary $H$. influenzae in pure culture and thus, it is, similar to the clinical situation, in which $H$. influenzae is in the majority amongst many organisms isolated from sputum. ${ }^{26}$

Previous agar bead models with $P$. aeruginosa have demonstrated that there are differences between bacterial strains with respect to pulmonary persistence. ${ }^{12,16,17}$ Strains producing exotoxin A and elastase appear to have increased persistence, which correlates with increased pulmonary pathology. ${ }^{17}$ 
Exotoxin $\mathrm{S}$ does not appear to be critical for colonisation but its presence is associated with increased pulmonary damage. ${ }^{16}$ Although $H$. influenzae does not appear to produce exotoxins, liberated LOS may be the primary pathogenic entity, and further experiments could compare various strains possessing different LOS moieties. ${ }^{27,}{ }^{28}$ Although LOS of $H$. influenzae is considered to be less toxic than the LPS of Escherichia coli, ${ }^{29}$ the binding of LOS to lung surfactant may increase its toxicity. ${ }^{30}$

Encasement of $\boldsymbol{H}$. influenzae into agar beads appears to facilitate resistance to normal cellular lung defence mechanisms as well as allowing infection. This occurs despite the presence of naturally occurring antibodies, which appear to be largely anti-LOS antibodies, in both serum and lung lavage fluid. Mice also appear to have low levels of naturally occurring anti-haemophilus antibodies in serum and lung lavage fluid. ${ }^{31}$ The situation is similar to that in COPD patients who probably acquire anti-haemophilus antibodies early in life ${ }^{32}$ but still succumb to pulmonary infections. Furthermore, in this rat model, the serum and lung lavage titres increased 7-10-fold during the course of the infection, depending on the bacterial inoculum. In this way, such infected rats are similar to $C F,{ }^{33}$ chronic bronchitis ${ }^{5}$ and bronchiectasis ${ }^{34}$ patients who almost uniformly have increased anti-haemophilus serum titres compared to normal subjects. Patients with $H$. influenzae respiratory tract infections also have antibodies that react with $\mathrm{OMPs}^{34,35}$ or LOS. $^{34,36,37}$ Furthermore, a recent study demonstrated elevated levels of anti-haemophilus OM IgG and $\operatorname{IgA}$, but not IgM, in the serum of COPD patients compared to controls. ${ }^{38}$ Rats chronically colonised with $P$. aeruginosa develop immune responses towards exotoxin A, elastase and slime layer, but apparently not towards protease. ${ }^{13}$ The dynamics of antibody response is rapid but biphasic for exotoxin A, slow for LPS and delayed for slime-layer antigens $;{ }^{13}$ increases in serum antibody to alginate also occur. ${ }^{18}$ Furthermore, antibody responses towards OMPs, including phenotypically-expressed iron-regulated OMPs, and LPS also occur. ${ }^{15}$ In the present study, a rapid rise in titre was observed when OMs (OMPs plus LOS) were used as antigen, which was apparently faster than the rise in anti-LOS titre alone. As immunoblotting demonstrated an early immune response towards OMPs, these surface-associated antigens may be more potent inducers of the immune system, perhaps more so than LOS, and may represent a tapping of immunological memory, perhaps for cross-reactive antibodies. The use or purified OMP antigens in immune-response detection systems should clarify this.

The presence of specific anti- $\boldsymbol{H}$. influenzae antibodies in lung lavage fluid of rats is similar to the situation with sputum from patients with unspecified COPD, ${ }^{38}$ bronchiectasis ${ }^{34}$ or chronic bronchitis, ${ }^{39}$ which contains anti- $H$. influenzae $\operatorname{IgG}$ and $\operatorname{IgA}$ antibodies. The antibodies detected in lung lavage fluid may represent locally produced IgG antibodies, but this finding must be viewed cautiously because of the lavage technique, as well as the apparent increase in serum proteins in sputum during bacterial exacerbations of chronic bronchitis. ${ }^{40}$ Indeed, in COPD patients, only sputum $\operatorname{IgA}$, and not $\operatorname{IgG}$, originates from a local source. ${ }^{38}$ Furthermore, intratracheal administration of $H$. influenzae antigen can result in the appearance of antibodies only in serum and not in lung lavage fluid. ${ }^{41}$

Antibodies directed against NT $H$. influenzae OMPs and LOS have been detected in the serum of mice vaccinated intraperitoneally. ${ }^{31,41}$ However, antibodies reactive with $H$. influenzae OMPs appeared only in the lung lavage fluid following intratracheal challenge of intraperitoneally immunised mice. ${ }^{41}$ Such antibodies were found to be opsonic and not bactericidal, and correlated with increased clearance of the challenge inoculum. ${ }^{41}$ In the present study, despite the increase in lung lavage fluid (and serum) antibodies, there was no apparent decrease in net pulmonary bacterial load. Resistance to these antibodies may be in part due to: (1) inaccessibility of antigens afforded by the agar beads; (2) low complement activity, as lung lavage fluid appears to contain only low amounts of complement components $;^{42,43}$ (3) poor opsonic activity of antibodies induced by intratracheal antigen presentation, ${ }^{41}$ which is in contrast to the protection afforded by active immunisation via non-respiratory tract antigen presentation routes, or by passive immunisation via the systemic circulation; ${ }^{41}(4)$ induction of blocking IgA antibodies; ${ }^{44}$ (5) possible phenotypic shift to increased resistance to anti-LOS antibodies, as occurs in $H$. influenzae type $b^{45}$

Antibodies produced during this infection crossreacted with OMPs of at least one other NT $H$. influenzae strain of different OMP profile. This appears to mimic the case with COPD patients, ${ }^{5}$ who present an antibody profile reactive to several H. influenzae strains. Extensive cross-reactivity of serum antibodies of COPD patients (and healthy controls) towards $H$. influenzae OMPs occurs, and this cross-reactivity extends to antibodies present in sputum. ${ }^{38}$ Although not studied as comprehensively, similar cross reactivity occurs with IgG antibodies in the serum and lung lavage fluid of chronically infected rats (fig. 4). The extent of common epitopes within OMPs of NT $H$. influenzae strains has been examined previously ${ }^{5}$ suggesting that extensive cross-reactivity can occur, particularly with the OMPs of $c .40 \mathrm{Kda}$. This model may be useful for the examination of the protective effect of cross-reactive antibodies induced by immunisation with a single isolate of NT $H$. influenzae, as has been reported in chronic bronchitis patients. ${ }^{46,47}$

This experimental model is amenable to antibiotic therapy, indicating retention of susceptibility by the bacteria and sufficient penetration of amoxycillin into the agar bead to attain bactericidal concentrations. Amoxycillin would appear to be an effective antibiotic capable of eradicating pulmonary $H$. influenzae in this 
experimental model, as it is in patients with bronchiectasis, ${ }^{48} \mathrm{CF},{ }^{2,3}$ and chronic bronchitis. ${ }^{49,50}$ Despite an initial decrease after antibiotic treatment, pulmonary $H$. influenzae increased in numbers in the rat lung (fig. 4), presumably due to insufficient antimicrobial treatment; however, use of this protocol may mimic the recolonisation of patients' sputum that can occur soon after cessation of antibiotic therapy. ${ }^{48}$

This work was supported by grants from the Medical Research Council and the Cystic Fibrosis Research Trust awarded to M.R.W.B., S.H.S. and T.O.R. T.O.R. thanks the Medical Research Council of Canada for a postdoctoral fellowship. We thank E. Grant for excellent and untiring technical help, and G. Morris, M. Ruglys, D. Cochrane and O. Zak for helpful comments. Part of this work was done at Ciba-Geigy Ltd, Basel, and we thank S. Kunz, J. Vaxalaire and B. Hengstler for their assistance.

\section{References}

1. Reynolds HY. Chronic bronchitis and acute infectious exacerbations. In: Mandell, GL, Douglas RG, Bennett JE (eds) Principles and practice of infectious diseases, 2nd edn. New York, John Wiley and Sons, 1985: 387-390.

2. Pressler T, Szaff M, Høiby N. Antibiotic treatment of Haemophilus influenzae and Haemophilus parainfluenzae infections in patients with cystic fibrosis. Acta Paediatr Scand $1984 ; 73$ : $541-547$.

3. Pedersen M, Støvring S, Mørkassel E, Koch C, Høiby N. A comparative study of amoxycillin and pivampicillin in persistent Heamophilus influenzae infection of the lower respiratory tract in children with chronic lung disease. Scand J Infec Dis 1986; 18 : 245-254.

4. Tager I, Speizer FE. Role of infection in chronic bronchitis. $N$ Engl J Med 1975; 292: 563-571.

5. Murphy TF, Apicella MA. Nontypable Haemophilus influenzae: a review of clinical aspects, surface antigens, and the human immune response to infection. Rev Infect Dis 1987; 9: $1-15$.

6. Cole P. A new look at the pathogenesis and management of persistent bronchial sepsis. In: Davies RJ (ed) Strategies for the management of chronic bronchial sepsis. Oxford, Medicine Publishing Foundation, Symposium Series 12. 1984: 1-20.

7. Marks MI. The pathogenesis and treatment of pulmonary infections in patients with cystic fibrosis. $J$ Pediatr 1981 ; 98: 173-179.

8. Denny FW. Effect of a toxin produced by Haemophilus influenzae on ciliated respiratory epithelium. J Infect Dis 1974; 129: 93-100.

9. Johnson AP, Inzana TJ. Loss of ciliary activity in organ cultures of rat trachea treated with lipo-oligosaccharide from Haemophilus influenzae. J Med Microbiol 1986; 22: 265268.

10. Sheinman BD, Devalia JL, Davies RJ, Crook SJ, Tabaqchali S. Synthesis of histamine by Haemophilus influenzae. $\mathrm{Br}$ Med J 1986; 292: 857-858.

11. Devalia JL, Grady D, Harmanyeri Y, Tabaqchali S, Davies RJ. Histamine synthesis by respiratory tract microorganisms: possible role in pathogenicity. $J$ Clin Pathol $1989 ; 42$ : 516-522.

12. Cash HA, Woods DE, McCullough B, Johanson WG, Bass JA. A rat model of chronic respiratory infection with Pseudomonas aeruginosa. Am Rev Respir Dis 1979; 119: 453-459.

13. Cash HA, Straus DC, Bass JA. Pseudomonas aeruginosa exoproducts as pulmonary virulence factors. Can J Microbiol 1983; 29 : 448-456.

14. Lam J, Chan R, Lam K, Costerton JW. Production of mucoid microcolonies by Pseudomonas aeruginosa within infected lungs in cystic fibrosis. Infect Immun 1980; 28: 546-556.

15. Cochrane DMG, Brown MRW, Anwar H, Weller PH, Lam K, Costerton JW. Antibody response to Pseudomonas aeruginosa surface protein antigens in a rat model of chronic lung infection. J Med Microbiol 1988; 27: 255-261.
16. Nicas TI, Frank DW, Stenzel P, Lile JD, Iglewski BH. Role of exoenzyme $\mathrm{S}$ in chronic Pseudomonas aeruginosa lung infections. Eur J Clin Microbiol 1985; 4: 175-179.

17. Woods DE, Cryz SL, Friedman RL, Iglewski BH. Contribution of toxin A and elastase to virulence of Pseudomonas aeruginosa in chronic lung infections of rats. Infect Immun $1982 ; 36$ : 1223-1228.

18. Woods DE, Bryan LE. Studies on the ability of alginate to act as a protective immunogen against infection with $P$ seudomonas aeruginosa in animals. J Infect Dis 1985 ; 151 : 581 588.

19. Slater LN. A rat model of prolonged non-lethal pulmonary infection due to nontypeable (unencapsulated) Haemophilus influenzae. 86th Annual Meeting of the American Society for Microbiology 1986; Abstract B-195.

20. Slater LN, Van Meter D, Emmons S. Effects of modification of host defences upon the duration of infection in a rat model of persistent pneumonia due to nontypable (unencapsulated) Haemophilus influenzae. 87th Annual Meeting of the American Society for Microbiology 1987; Abstract B-87.

21. Lowry OH, Rosebrough NJ, Farr AL, Randall RJ. Protein measurement with the folin phenol reagent. $J$ Biol Chem 1951 ; 193: 265-275.

22. Galanos C, Lüderitz $\mathrm{O}$, Westphal $\mathrm{O}$. A new method for the extraction of R lipopolysaccharide. Eur J Biochem 1969; 9: 245-249.

23. Niven DF, Donga J, Archibald FS. Responses of Haemophilus pleuropneumoniae to iron restriction: changes in the outer membrane protein profile and the removal of iron from porcine transferrin. Mol Microbiol 1989; 3: 1083-1089.

24. Towbin H, Staehelin T, Gordon J. Electrophoretic transfer of proteins from polyacrylamide gels to nitrocellulose sheets: procedure and some applications. Proc Natl Acad Sci USA $1979 ; 76: 4350-4354$.

25. Woods DE, Franklin R, Cryz SJ, Ganss M, Peppler M, Ewanowich C. Development of a rat model for respiratory infection with Bordetella pertussis. Infect Immun 1989; 57: 1018-1024.

26. Jensen T, Pedersen SS, Stafanger G, Høiby N, Koch C, Bondesson G. Comparison of amoxycillin/clavulanate with amoxycillin in children and adults with chronic obstructive pulmonary disease and infection with Haemophilus influenzae. Scand J Infect Dis 1988; 20: 517-524.

27. Inzana TJ. Electrophoretic heterogeneity and interstrain variation of the lipopolysaccharide of Haemophilus influenzae. J Infect Dis 1983; 148: 492-499.

28. Apicella MA, Dudas KC, Campagnari A, Rice P, Mylotte JM, Murphy TF. Antigenic heterogeneity of lipid A of Haemophilus influenzae. Infect Immun 1985; 50: 9-14.

29. Flesher AR, Insel RA. Characterization of the lipopolysaccharide of Haemophilus influenzae. J Infect Dis 1978; 138: 719730.

30. Brogden KA, Cutlip RC, Lehmkuhl HD. Complexing of bacterial lipopolysaccharide with lung surfactant. Infect Immun 1986; 52: 644-649.

31. Hansen EJ, Hart DA, McGehee JL, Toews GB. Immune enhancement of pulmonary clearance of nontypable Haemophilus influenzae. Infect Immun 1988; 56: 182-190.

32. Burns MW, May JR. Bacterial precipitins in serum of patients with cystic fibrosis. Lancet 1968; 1: 270-272.

33. Spinola SM, Peacock J, Denny FW, Smith DL, Cannon JG. Epidemiology of colonization by nontypable Haemophilus influenzae in children: a longitudinal study. $J$ Infect Dis $1986 ; 154: 100-109$.

34. Maciver I, Hill SH, O'Reilly T, Burnett D, Stockley RA, Brown MRW. Immune response of patients with bronchiectasis to outer membrane antigens of non-typable Haemophilus influenzae. Thorax 1988; 43: 861P.

35. Hansen MV, Musher DM, Baughn RE. Outer membrane proteins of nontypable Haemophilus influenzae and reactivity of paired sera from infected patients with their homologous isolates. Infect Immun 1985; 47: 843-846.

36. Clarke $\mathrm{CW}$. In vivo and in vitro reactions to antigens of Haemophilus influenzae in bronchial obstruction. Br J Dis Chest 1979; 73: 373-381.

37. Harada T, Sakakura Y. Immunologic responses against lipopolysaccharide of Hemophilus influenzae in patients with acute sinusitis. Ann Otol Rhinol Laryngol 1988; 97: 207210 . 
38. Groeneveld K, Eijk PP, Van Alphen L, Jansen HM, Zanen HC. Haemophilus influenzae infections in patients with chronic obstructive pulmonary disease despite specific antibodies in serum and sputum. Am Rev Respir Dis 1990; 141 : 1316-1321.

39. Gump DW, Christmas WA, Forsyth BR, Phillips CA, Stouch WH. Serum and secretory antibodies in patients with chronic bronchitis. Arch Intern Med 1973; 132: 847-851.

40. Stockley RA, Burnett D. Alpha ${ }_{1}$-antichymotrypsin in infected and noninfected sputum. Am Rev Respir Dis 1980;122:8188.

41. McGehee JL, Radolf JD, Toews GB, Hansen EJ. Effect of primary immunization on pulmonary clearance of nontypable Haemophilus influenzae. Am J Resp Cell Mol Biol 1989; 1: 201-210.

42. Reynolds HY, Thompson RE. Pulmonary host defenses. 1. Analysis of protein and lipids in bronchial secretions and antibody responses after vaccination with Pseudomonas aeruginosa. J Immunol $1973 ; 111$ : 358-368.

43. Reynolds HY, Newball HH. Analysis of proteins and respiratory cells obtained from human lungs by bronchial lavage. $J$ Lab Clin Med 1974; 84 : 559-573.

44. Musher DM, Goree A, Baughn RE, Birdsall HH. Immunoglobulin A from bronchopulmonary secretions blocks bacteri- cidal and opsonizing effects of antibody to nontypable Haemophilus influenzae. Infect Immun 1984; 45: 36-40.

45. Inzana TJ, Anderson P. Serum factor-dependent resistance of Haemophilus influenzae type $\mathrm{b}$ to antibody to lipopolysaccharide. $J$ Infect Dis 1985;151: 869-877.

46. Clancy R, Cripps A, Muree-Allen K, Yeung S, Engel M. Oral immunisation with killed Haemophilus influenzae for protection against acute bronchitis in chronic obstructive lung disease. Lancet 1985; 2: 1395-1397.

47. Clancy RL, Cripps AW, Gebski V. Protection against recurrent acute bronchitis after oral immunization with killed Haemophilus influenzae. Med J Aust 1990; 152: 413-416.

48. Hill SL, Morrison HM, Burnett D, Stockley RA. Short term response of patients with bronchiectasis to treatment with amoxycillin given in standard or high doses orally or by inhalation. Thorax 1986; 41 : 559-565.

49. Cole PJ, Roberts DE, Davies SF, Knight RK. A simple oral antimicrobial regimen effective in severe chronic bronchial suppuration associated with culturable Haemophilus influenzae. J Antimicrob Chemother 1983; 11 : 109-113.

50. Maesen FPV, Davies BI, Baur C. Amoxycillin/clavulanate in acute purulent exacerbations of chronic bronchitis. $J$ Antimicrob Chemother 1987; 19 : 373-383. 